\title{
Seasonal and successional dynamics of size-dependent plant demographic rates in a tropical dry forest
}

Irving Saenz ${ }^{1}$, Richard Feldman ${ }^{1}$, Casandra Reyes-García ${ }^{1}$, Jorge A. Meave ${ }^{2}$, Luz Maria Calvo-Irabien ${ }^{1}$, Filogonio May-Pat ${ }^{1}$, Juan M. Dupuy ${ }^{\text {Corresp. } 1}$

${ }^{1}$ Unidad de Recursos Naturales, Centro de Investigación Científica de Yucatán, Mérida, Yucatán, México

2 Departamento de Ecología y Recursos Naturales, Facultad de Ciencias, Universidad Nacional Autónoma de México, Coyoacán, Ciudad de México, Ciudad de México, México

Corresponding Author: Juan M. Dupuy

Email address: jmdupuy@cicy.mx

Tropical forests are globally important for biodiversity conservation and climate change mitigation but are being converted to other land uses. Conversion of seasonally dry tropical forests (SDTF) is particularly high while their protection is low. Secondary succession allows forests to recover their structure, diversity and composition after conversion and is influenced by demographic rates of the constituent species. However, how these rates vary between seasons for different plant-sizes at different successional stages in SDTF is not known. The effect of seasonal drought may be more severe early in succession, when temperature and radiation are high, while competition and densitydependent processes may be more important at later stages, when vegetation is tall and dense. Besides, the effects of seasonality and successional stage may vary with plant size. Large plants can better compete with small plants for limiting resources and may also have a greater capacity to withstand stress. We asked how size-dependent density, species density, recruitment and mortality varied between seasons and successional stages in a SDTF. We monitored a chronosequence in Yucatan, Mexico, over six years in three 0.1 ha plots in each of three successional stages: early (3-5 years-old), intermediate (18-20 years-old) and advanced ( $>50$ years-old). Recruitment, mortality and species gain and loss rates were calculated from wet and dry season censuses separately for large (diameter $>5 \mathrm{~cm}$ ) and small $(1-5 \mathrm{~cm}$ in diameter) plants. We used linear mixed-effects models to assess the effects of successional stage, seasonality and their changes through time on demographic rates and on plant and species density. Seasonality affected demographic rates and density of large plants, which exhibited high wet-season recruitment and species gain rates at the early stage and high wet-season mortality at the intermediate stage, resulting in an increase in plant and species density early in succession followed by a subsequent stabilization. Small plant density decreased steadily after only 5 years of land abandonment, whereas species density increased with 
successional stage. A decline in species dominance may be responsible for these contrasting patterns. Seasonality, successional stage and their changes through time had a stronger influence on large plants, likely because of large among-plot variation for small plants. Notwithstanding the short duration of our study, our results suggest that climatechange driven decreases in rainy season precipitation may have an influence on successional dynamics in our study forest as strong as, or even stronger than, prolonged or severe droughts during the dry season. 
2 Seasonal and successional dynamics of size-dependent 3 plant demographic rates in a tropical dry forest

6 Irving Saenz ${ }^{1}$, Richard E. Feldman ${ }^{1}$, Casandra Reyes-García ${ }^{1}$, Jorge A. Meave ${ }^{2}$, Luz María

7 Calvo-Irabien ${ }^{1}$, Filogonio May-Pat ${ }^{1}$, Juan Manuel Dupuy ${ }^{1}$

8

$9 \quad{ }^{1}$ Unidad de Recursos Naturales, Centro de Investigación Científica de Yucatán, Mérida, 10 Yucatán, México

$11{ }^{2}$ Departamento de Ecología y Recursos Naturales, Facultad de Ciencias, Universidad Nacional 12 Autónoma de México, Coyoacán, Ciudad de México, México

14 Corresponding Author:

15 Juan Manuel Dupuy ${ }^{1}$

16 Calle 43 \# 130, Col. Chuburná de Hidalgo, Mérida, Yucatán, 97205, México

17 Email address: jmdupuy@,cicy.mx 
19

20

21

22

23

24

25

26

27

28

29

30

31

32

33

34

35

36

37

38

39

40

41

42

43

44

45

46

47

48

49

50

51

52

53

54

55

56

57

58

\section{Abstract}

Tropical forests are globally important for biodiversity conservation and climate change mitigation but are being converted to other land uses. Conversion of seasonally dry tropical forests (SDTF) is particularly high while their protection is low. Secondary succession allows forests to recover their structure, diversity and composition after conversion and is influenced by demographic rates of the constituent species. However, how these rates vary between seasons for different plant-sizes at different successional stages in SDTF is not known. The effect of seasonal drought may be more severe early in succession, when temperature and radiation are high, while competition and density-dependent processes may be more important at later stages, when vegetation is tall and dense. Besides, the effects of seasonality and successional stage may vary with plant size. Large plants can better compete with small plants for limiting resources and may also have a greater capacity to withstand stress. We asked how size-dependent density, species density, recruitment and mortality varied between seasons and successional stages in a SDTF. We monitored a chronosequence in Yucatan, Mexico, over six years in three 0.1 ha plots in each of three successional stages: early (3-5 years-old), intermediate (18-20 years-old) and advanced ( $>50$ years-old). Recruitment, mortality and species gain and loss rates were calculated from wet and dry season censuses separately for large (diameter $>5 \mathrm{~cm}$ ) and small (1$5 \mathrm{~cm}$ in diameter) plants. We used linear mixed-effects models to assess the effects of successional stage, seasonality and their changes through time on demographic rates and on plant and species density. Seasonality affected demographic rates and density of large plants, which exhibited high wet-season recruitment and species gain rates at the early stage and high wetseason mortality at the intermediate stage, resulting in an increase in plant and species density early in succession followed by a subsequent stabilization. Small plant density decreased steadily after only 5 years of land abandonment, whereas species density increased with successional stage. A decline in species dominance may be responsible for these contrasting patterns. Seasonality, successional stage and their changes through time had a stronger influence on large plants, likely because of large among-plot variation for small plants. Notwithstanding the short duration of our study, our results suggest that climate-change driven decreases in rainy season precipitation may have an influence on successional dynamics in our study forest as strong as, or even stronger than, prolonged or severe droughts during the dry season.

\section{Introduction}

Tropical forests are globally important reservoirs of biodiversity and play a major role in the global carbon cycle (Pan et al., 2011; Slik et al., 2015), but are being converted to agricultural and pasturelands at alarming rates (FAO, 2015). Conversion of seasonally dry tropical forests (SDTF) is particularly high, while their protection is low, making them one of the most threatened ecosystems worldwide (Janzen, 1988; Miles et al., 2006; Aide et al., 2013). At present, this biome consists mainly of secondary vegetation re-growing after converted land is abandoned (Sánchez- 
59

60

61

62

63

64

65

66

67

68

69

70

71

72

73

74

75

76

77

78

79

80

81

82

83

84

85

86

87

88

89

90

91

92

93

94

95

96

97

98

Azofeifa \& Portillo-Quintero, 2011). Understanding tropical forest succession is therefore essential to elucidate the role of secondary forests in biodiversity conservation (Derroire et al., 2016; Rozendaal et al., 2019), carbon dynamics and climate change mitigation (Saatchi et al., 2011; Becknell et al., 2012; Chazdon et al., 2016). How the structure, diversity and composition of regenerating communities change during secondary succession is influenced by the aggregated demographic rates of the constituent species: recruitment, growth and mortality (van Breugel et al., 2006; Rozendaal \& Chazdon, 2015; Muscarella et al., 2017; Rozendaal et al., 2017). However, given the dominance of annual surveys in the study of SDTF succession, it has not been possible to assess how these demographic rates are influenced by seasonality and if the effects of seasonality vary along succession and with plant size. Climate change may affect the duration and severity of dry-season drought, and the amount of rainy season precipitation (Allen et al., 2017), emphasizing the need to understand the effects of seasonality on plant demographic rates along SDTF secondary succession.

Generally, tropical forests can recover their structure and diversity within a few decades after land abandonment through secondary succession (Guariguata \& Ostertag, 2001; Chazdon, 2014; Poorter et al., 2016), although recovery of their species composition may take centuries (Rozendaal et al., 2019). In particular, plant density can recover quickly but at rates that vary tremendously among individual forest stands (Aide et al., 2000; Kennard, 2002; Chazdon et al., 2007; LebrijaTrejos et al., 2008). The fast recovery of plant density is strongly associated with high recruitment rates resulting from a combination of resprouting of remnant vegetation and germination of seeds either stored in the soil seedbank or dispersed into the site (seed rain) after agricultural lands are abandoned (Chazdon, 2014). Species density (the number of species per sampled area) also increases over succession in tropical forests (Guariguata \& Ostertag, 2001; Chazdon et al., 2007). Although species density is tightly linked to plant density (Denslow, 1995; Guariguata \& Ostertag, 2001), strong dominance by one or few species can lead to a decoupling of these two forest attributes (Mesquita et al., 2001; Dupuy et al., 2012). Strong dominance can also strongly influence community-level demographic rates - growth, recruitment and mortality- in tropical forests (van Breugel et al. 2006).

Rainfall seasonality interacts with environmental gradients underlying SDTF succession. As succession proceeds and aboveground biomass recovers, the abiotic environment shifts from water-stressed conditions (i.e., high temperature, solar radiation and water vapor-pressure deficit, and low soil water content) in recently abandoned stands to moister, cooler and shadier environments in older stands (Lebrija-Trejos et al., 2011; Pineda-García et al., 2013). Thus, the harsh conditions that prevail early in succession may be further exacerbated during the dry season and represent an even stronger filter to plant survival, compared to the more mesic conditions of late-successional stages, which may somewhat buffer water stress during the dry season (McLaren \& McDonald, 2003; Lebrija-Trejos et al., 2010b; Maza-Villalobos et al., 2013). Seasonality delineates temporal patterns of carbon assimilation in SDTF constraining growth and recruitment mostly to the rainy season, whereas drought during the dry season can strongly reduce plant establishment and growth and increase mortality risk (Murphy \& Lugo, 1986; Khurana \& Singh, 
99

100

101

102

103

104

105

106

107

108

109

110

111

112

113

114

115

116

117

118

119

120

121

122

123

124

125

126

127

128

129

130

131

132

133

134

135

136

137

138

2001; Ceccon et al., 2006; Becknell et al., 2012; Alberton et al., 2019; Campos et al., 2019) especially early in succession. Although seasonality affects SDTF regeneration and secondary succession processes, few studies have examined effects of seasonality on plant community dynamics during SDTF succession (Lebrija-Trejos et al., 2011; Maza-Villalobos et al., 2013).

Plant successional patterns and the underlying demographic rates can vary with plant size. Successional patterns of plant and species density are known to be size dependent, with smaller plants recovering earlier in succession and showing greater variation among forest stands than larger plants (Guariguata \& Ostertag, 2001; Kennard, 2002; Dupuy et al., 2012). This may be partly due to strong dominance in small plants and a decrease in dominance and increase in diversity with increasing plant size, as a result of density-dependent processes and community compensatory trends operating on plant ontogeny (Webb \& Peart, 1999; Harms et al., 2000). Moreover, large plants have a more developed root and shoot system, which allows them greater access to resources and confers them greater capacity to store carbon and water than small plants (Schwinning \& Weiner, 1998; Niinemets, 2010; Ma et al., 2016). Therefore, size-asymmetric competition favors large-size plants, resulting in higher growth and lower mortality rates compared to small plants (van Breugel et al. 2006). Large plants may also have a greater capacity to withstand biotic and abiotic stress than small plants, although, at the higher end of the plant size spectrum, a recent study in an Amazonian SDTF found that large trees are actually more vulnerable to xylem embolism and drought stress, and may suffer greater drought-related mortality than smaller ones (Brum et al., 2019). Seasonal variation in microenvironmental conditions (Lebrija-Trejos et al., 2011; Méndez-Alonzo et al., 2013) and size-asymmetric competition both vary along secondary succession (van Breugel et al. 2006; Chazdon 2014) and differentially affect large and small plants. Therefore, interacting effects of plant size, seasonality and successional age on SDTF dynamics can reasonably be expected. However, to our knowledge, our study is the first to assess plant sizedependent seasonal and successional dynamics (temporal changes in density, species density, recruitment and mortality) in a SDTF.

We use a chronosequence resampling approach over six years to examine successional and seasonal dynamics of demographic processes (recruitment and mortality) and of plant and species density of woody vegetation in two size classes: large (diameter at breast height, or $\mathrm{dbh}>5 \mathrm{~cm}$ ) and small $(\mathrm{dbh} 1-5 \mathrm{~cm})$ plants in a SDTF in the Yucatan Peninsula, Mexico. We address the following questions: (1) How does community dynamics of woody plants vary between seasons and successional age categories? (2) (How) do large- and small-size plants differ in their successional and seasonal dynamics? We hypothesize that the successional patterns of plant and species density, and the underlying demographic rates: $(\mathrm{H} 1)$ differ between seasons, reflecting successional and seasonal differences in key biotic (competition) and abiotic (water availability) factors; (H2) differ between large and small plants, reflecting size-dependent capacities to acquire, store and compete for limiting resources, and to withstand biotic and abiotic stressors. We predict that (P1) for large plants, plant and species density will rapidly increase early in succession (reflecting early colonization), especially during the wet season (when water availability is less limiting), and gradually stabilize in intermediate and advanced stages (due increased competition 
139 in dense-cover, closed-canopy conditions); and that (P2) for small plants, after an initial increase, 140 plant density will decline at intermediate and advanced successional stages (reflecting size141 asymmetric competition), especially during the dry season (when water availability is most 142 limiting), whereas species density will gradually stabilize (reflecting lower dominance and higher 143 diversity). In line with these expected patterns of density, we predict that (P3) in early succession, 144 recruitment and species gain rates will be high and mortality will be low for both large and small 145 plants (especially in the wet season), while (P4) at intermediate and late successional stages all 146 rates will be low for both large and small plants (as plant and species density gradually stabilize) except for (P5) high mortality rates of small plants (especially in the dry season).

\section{Materials \& Methods}

\section{Study area}

The study was conducted within and around Kaxil Kiuic Biocultural Reserve (KKBR) in the center of the Yucatan Peninsula, Mexico (Figure 1). Permission to access and conduct research in KKBR was granted by its Director, James M. Callaghan. Access to field sites on communal lands outside KKBR was verbally approved by don Evelio Uc Uc on behalf of the community of Xkobenhaltun. The climate is tropical, warm, subhumid, of the Aw type according to the Köppen-Geiger climate classification (Peel et al., 2007). Mean annual precipitation is $841 \mathrm{~mm}$, but annual precipitation varies greatly from $703 \mathrm{~mm}$ to $1092 \mathrm{~mm}$, with over two thirds of the yearly total falling during the rainy season (June-October), followed by a dry season with scattered rains (16-76 mm per month) from November to May (Figure S1; Orellana et al., 1999). Mean annual temperature is $25.1^{\circ} \mathrm{C}$, but annual variation is high, with mean maximum temperatures of $36.1^{\circ} \mathrm{C}$ at the end of the dry season (Jackson et al., 2018), which results in high vapor pressure deficit (mean of $2 \mathrm{kPa}$, compared to the wet season (mean of $0.5 \mathrm{kPa}$ ) (CachPérez et al., 2018)). The predominant vegetation is seasonally dry semi-deciduous tropical forest in which $50-75 \%$ of plants shed their leaves during the dry season. Canopy height ranges between 13-18 m, although vegetation structure varies with stand age, topography and soil properties (Dupuy et al., 2012). The study area has been subjected to extensive logging and clearing for traditional slash and burn agriculture, which requires a constant rotation of croplands due to the loss of soil fertility after two or three crops (Lara Ponce et al., 2012; Gunn, 2015). Consequently, the landscape is a diverse and shifting mosaic of croplands and forest stands of different fallow ages (Rico-Gray \& García-Franco, 1991).

172

\section{Sampling design}

174 Nine permanent plots $(20 \times 50 \mathrm{~m})$ were established in September and October 2009 in sites of similar conditions, which differ in fallow age. All plots are located on forest stands on flat areas 
177 agricultural practices within a fairly continuous matrix of secondary forests. Sites were used for 178 fuel-wood extraction (mostly dead and/or fallen branches and stems) and experienced occasional 179 poaching during forest regrowth.

180 Stand age (i.e. the number of years since a stand was abandoned) was determined from 181 interviews with local residents who had lived in the area for at least 50 years and with knowledge 182 of how the land was used by their parents in the decades prior to their birth. Mayan peasants in 183 the Yucatan have developed their own detailed classification of successional stages, which is 184 tightly linked to their traditional "milpa" system of slash-and-burn agriculture (González-Cruz et 185 al. 2015), enabling a fairly accurate assessment of successional age of secondary forests. We 186 categorized our study sites into three successional-age categories: (1) 3 to 5 year-old stands 187 (hereafter named early-stage); (2) 18 to 20 year-old stands (intermediate stage); (3) $>50$ year-old 188 stands (advanced stage; Table S1).

189

190

191

192

193

194

195

196

197

198

199

200

201

202

203

204

205

206

207

208

209

210

211

212

Within each $20 \times 50 \mathrm{~m}$ plot, we recorded, tagged, identified and measured woody plants $>5 \mathrm{~cm}$ dbh (mostly canopy trees, hereafter large plants) in ten $10 \times 10 \mathrm{~m}$ quadrats, and plants $1-5 \mathrm{~cm}$ $\mathrm{dbh}$ (small -mostly understory-plants) in nested $5 \times 6$ m quadrats. Specimens of plants that could not be identified in the field were collected and identified using a regional reference collection from the CICY herbarium at the Centro de Investigación Científica de Yucatán.

Plants were initially measured at the end of the rainy season (September-October) of 2009 and approximately every six months (April-May, that is, at the end of the dry season) thereafter until 2015 , to capture seasonal and inter-annual variation in woody plant community dynamics. Thus, following the initial inventory, a total of 12 censuses were conducted: six in the rainy season and six in the dry season. During these censuses, we measured the diameter of each stem and recorded individuals that had died or recruited into each plant size-category.

\section{Statistical analysis}

We assessed plant density (number of individuals/ha) and species density (number of species/plot), using the total area of 0.1 ha for large-size plants and 0.03 ha for small-size plants. For each plot, we calculated recruitment, mortality, species gain, and species loss rates in each census along the 6-year study period (2010 to 2015). These calculations considered plant size categories separately and included the values of the first census (the wet season of 2009) as the initial community. Seasonal demographic rates were calculated every six months (182.625 days), taking into account the periodicity of the censuses.

Plant recruitment rate was calculated as:

$$
\mathrm{R}=\left([(\mathrm{n}+\mathrm{r}) / \mathrm{n}]^{182.625 / \mathrm{t}}\right)-1
$$


213 where $\mathrm{n}$ is the number of plants present at the beginning of the season, $\mathrm{r}$ is the number of new

214 recruits into the size class recorded in the corresponding census and $t$ is the number of days

215 elapsed between two consecutive censuses.

216 Plant mortality rate was calculated as:

217

218

219

220

221

222

223

224

225

226

227

228

229

230

231

232

233

234

235

236

237

238

239

240

241

242

243

244

245

246

247

248

249

where $\mathrm{n}$ is the number of plants present at the beginning of the season, $\mathrm{d}$ is the number of plants that died between the previous census and the current one. Gain and loss rates of species were calculated using similar formulae, where $n$ is the number of species, $r$ the number of new species, and $\mathrm{m}$ the number of species lost from the previous census to the current one (Capers et al., 2005; Maza-Villalobos et al., 2013). We used linear mixed-effects models to assess the effects of successional stage, seasonality and their changes over time on each response variable. We included time (year) as a predictor variable, since we expected each response variable as well as the effect of seasonality (i.e. variation between the wet and the dry season) to vary over time, even within each successional stage.

Because we had data from three plots of the same successional stage with repeated measures over six years, we included plot as a random effect. We modeled a random intercept and a slope for successional stage meaning the year-one dry-season demographic rates and densities could vary among the three plots nested within the advanced stage (intercept), intermediate stage (successional stage effect level 1), and early stage (successional stage effect level 2). Since the inclusion of plant size class in a single model along with the other predictor variables would result in an unwieldy model with a four-way interaction and all the sub-interactions, and considering that our dataset is too small to support a model with so many parameter estimates, we used separate models for the two plant size categories: small plants $(1-5 \mathrm{~cm} \mathrm{dbh})$ and large plants ( $>5 \mathrm{~cm}$ dbh). Thus, we ran 12 models: six response variables (plant density, species density, recruitment, species gain rate, mortality and species loss rate) for the two size classes.

We related each community variable (Community $\left.{ }_{\mathrm{ij}}\right)$ to the fixed explanatory variables using the following model: Community $_{\mathrm{ij}}=\alpha+\beta_{1}\left[\right.$ Year $\left._{\mathrm{i}, \mathrm{j}}\right]+\beta_{2}\left[\right.$ Season $\left._{\mathrm{i}, \mathrm{j}}\right]+\beta_{3}\left[\right.$ Successional stage $\left._{\mathrm{i}, \mathrm{j}}\right]+$ $\beta_{4}\left[\right.$ Year $\left._{\mathrm{i}, \mathrm{j}}\right]$ [Season $\left._{\mathrm{i}, \mathrm{j}}\right]+\beta_{5}\left[\right.$ Year $\left._{\mathrm{i}, \mathrm{j}}\right]$ [Successional stage $\left.\mathrm{i}, \mathrm{j}\right]+\beta_{6}\left[\right.$ Season $\left._{\mathrm{i}, \mathrm{j}}\right]$ [Successional stage $\mathrm{i}, \mathrm{j}]+\beta_{7}$ [Year $\left._{\mathrm{i}, \mathrm{j}}\right]\left[\right.$ Season $\left._{\mathrm{i}, \mathrm{j}}\right]$ [Successional stage $\left.\mathrm{i}, \mathrm{j}\right]$

Where $i$ is the plot, $j$ is the census year, $\alpha$ is the intercept and $\beta$ is the parameter estimate. Thus, we included 12 parameter estimates, corresponding to the 12 levels of the interactions among two seasons, three successional stages and year (advanced stage $\times$ dry season [the overall 
250

251

252

253

254

255

256

257

258

259

260

261

262

263

264

265

266

267

268

269

270

271

272

273

274

275

276

277

278

279

280

281

282

283

284

285

286

287

288

intercept, $\alpha$ ], advanced $\times$ dry $\times$ year, advanced $\times$ wet season, advanced $\times$ wet $\times$ year, intermediate stage $\times$ dry, intermediate $\times$ dry $\times$ year, intermediate $\times$ wet, intermediate $\times$ wet $\times$ year, early stage $\times$ dry, early $\times$ dry $\times$ year, early $\times$ wet, early $\times$ wet $\times$ year $)$. We estimated the parameters of each model $(\alpha, \beta 1 \ldots)$ with the lmer function in the lme 4 package (Bates et al., 2015). Additionally, we used the lmerTest package (Kuznetsova et al., 2014) to add denominator degrees of freedom and p-values to the table of coefficients based on the standard settings of lmerTest (Satterthwaite's approximation). We present the results graphically by calculating the predicted seasonal trends in our variables along a six-year period in each of the three successional stages. Thus, by having the continuous variable, year, interact with the categorical variables, successional stage and season, we allowed the slope of the time series to vary by successional stage and season. We re-scaled the $\mathrm{x}$-axis to show the stand age by adding each consecutive census year to the age of each plot at the initial inventory (rainy season of 2009), which we set as 5 years for the early stage, 20 years for intermediate and 60 years for advanced, although we acknowledge that these ages are averages and the real age of each stand may be 1 5 years older or younger. Fitted values and 95\% confidence intervals for predicted values of models were obtained using parametric bootstrapping $(n=999)$ within the bootMer function in the lme 4 package (Bates et al., 2015) and visualized within the R package ggplot2 (Wickham, 2016).

For each response variable, we calculated the marginal (m) and the conditional (c) $R^{2}$ values using the r.squaredGLMM function in the MuMIn package (Barton, 2018). $R^{2} m$ indicates the variance explained by fixed effects only and $R^{2} c$ indicates the variance explained by both fixed and random effects (Nakagawa \& Schielzeth, 2013). All analyses were performed in R version 3.6.0 (R Development Core Team, 2012).

\section{Results}

\section{Plant and species density}

A total of 4,319 individual plants belonging to 120 species and 34 families were recorded in the total sampling area $(0.9 \mathrm{ha})$ during the six-year study period. Large plants $(\mathrm{DBH}>5 \mathrm{~cm})$ represented $32 \%$ of individuals in the community and encompassed 53 woody species in 18 families. Small-size plants (DBH 1-5 cm) accounted for $68 \%$ of the recorded individuals and belonged to 113 species distributed in 33 families.

Mean $( \pm \mathrm{SE})$ plant density increased with successional stage from $682.5 \pm 316.2 \mathrm{plants} / \mathrm{ha}$ in the early stage, to $1,320.5 \pm 235.7$ in the intermediate stage and 1,538.3 \pm 272.7 plants/ha in the advanced stage. The mean number of large plants increased markedly in the early stage from 288 \pm 81 plants/ha in the first study year (2010), to $1,132 \pm 174$ plants/ha in the last year and was higher in the wet than in the dry season, but seasonal differences were vastly reduced and plant densities stabilized in intermediate and advanced stages (Table S2; Figure 2 a-c). Species density of large-size plants showed a similar pattern, increasing with stand stage, and having a 
289

290

291

292

293

294

295

296

297

298

299

300

301

302

303

304

305

306

307

308

309

310

311

312

313

314

315

316

317

318

319

320

321

322

323

324

325

pronounced increment during the study period only in the early stage, but did not vary between seasons at any stage (Table S2; Figure 2 d-f).

In contrast to large plants, density of small plants decreased over time, especially in the advanced stage, and also decreased with successional stage from $11992.5 \pm 3087.0$ plants/ha in the early stage, to $7821.2 \pm 813.6$ in the intermediate stage and $6335.1 \pm 595.4$ plants/ha in the advanced stage, but did not vary between seasons (Table S3; Figure 2 g-i). Species density of small plants showed a very different pattern; it increased with successional stage and over time in the early stage but decreased over time in the intermediate and advanced stages (Table S3; Figure $2 \mathrm{j}-1$ ).

\section{Recruitment and species gain rates}

Both recruitment and species gain rates of large plants were highest and showed interannual and seasonal variation exclusively in the early stage. At this stage, both rates were higher in the rainy than in the dry season at the beginning of the study but decreased thereafter, converging to dry season values. At the intermediate and advanced stages, recruitment and species gain rates were small and did not vary between seasons or among years (Table S4; Figure 3 a-f). Recruitment and species gain rates of small plants were both very low and did not vary over the study period, between seasons or among successional stages (Table S5; Figure 3 g-1).

\section{Mortality and species loss rates}

Mortality of large plants was highest and showed significant interannual and seasonal variation only at the intermediate stage. At this stage, mortality was higher in the rainy than in the dry season at the beginning of the study and decreased thereafter converging to dry season values (Table S6; Figure 4 a-c). Species loss rates of large-size plants were generally low and showed no significant effect of any of the predictors or interactions evaluated, partly due to large amongplot variation (Table S6; Figure 4 d-f).

On the other hand, for small plants, mortality rate increased slightly with successional stage, with the highest values in the advanced stage (Table S7; Figure $4 \mathrm{~g}-\mathrm{i}$ ). Finally, species loss rates of small-size plants showed large among-plot (random) variation and no significant effect of any of the predictors or interactions (Table S7; Figure 4 j-1).

\section{Discussion}

Surprisingly, most studies of plant community dynamics along seasonally dry tropical forest (SDTF) succession are based on annual surveys, and hence fail to consider the potential effects of seasonality (Maza-Villalobos et al., 2011; Derroire et al., 2016; Rozendaal et al., 2017; Martínez-Ramos et al., 2018; but see Maza-Villalobos et al., 2013). To our knowledge, this is the first study to assess seasonal and successional dynamics of size-dependent plant demographic 
326

327

328

329

330

331

332

333

334

335

336

337

338

339

340

341

342

343

344

345

346

347

348

349

350

351

352

353

354

355

356

357

358

359

360

361

362

363

364

rates in a SDTF. We asked how community dynamics of woody plants vary among seasons and successional age categories and if large- and small-size plants differ in their successional and seasonal dynamics. We hypothesized that the successional patterns of plant and species density, and the underlying demographic rates would differ both between seasons and between large and small plants. We found marked differences in demographic rates and in plant and species density between large- and small-size plants between seasons, among successional stages and over the study period, but significant differences between seasons only for large plants. Large plants exhibited high wet-season recruitment and species gain rates at the early stage and high wetseason mortality at the intermediate stage (both decreasing with time), resulting in an increase in plant and species density early in succession and a subsequent stabilization. In contrast, demographic rates of small-size plants showed large among-plot (random) variation and almost no significant effects of time (year), seasonality or successional stage. However, small plant density decreased steadily after only 5 years of land abandonment, whereas species density increased with successional stage, likely reflecting strong dominance early in succession and greater diversity at later stages. Below we discuss the results in detail.

We predicted that plant and species density of large plants would increase early in succession and stabilize subsequently (P1), reflecting high recruitment and species gain and low mortality and species loss rates (P3). Our results clearly matched these predictions (Figures 2 a-f -4 a-f) and indicate that large-plant density and species density recover to old-growth forest values quickly, in line with previous findings in other SDTF (Aide et al., 2000; Lebrija-Trejos et al., 2008; Chazdon et al., 2011; Maza-Villalobos et al., 2011). Moreover, early successional recruitment and species gain rates were higher in the rainy than the dry season (Figure $3 \mathrm{a}, \mathrm{d}$ ), which is in line with findings of previous studies in SDTF indicating that seasonal water availability enhances plant growth and establishment (Holbrook et al., 1995; Dirzo et al., 2011; Gaviria \& Engelbrecht, 2015; Alberton et al., 2019; Campos et al., 2019). In SDTF, temperature, solar radiation and water vapor-pressure deficit are higher while soil water content is lower at the early successional stage compared to subsequent stages (Lebrija-Trejos et al., 2011; PinedaGarcía et al., 2013). Thus, early in succession, growth of saplings into the large size class is likely low during the dry season, occurring mostly during the wet season. Previous studies in SDTF have shown that many early successional species have a fast or acquisitive strategy maximizing water transport, photosynthesis and biomass accumulation when water is available, while minimizing water loss and respiration costs -hence, also photosynthesis and growth- by closing their stomata or shedding their leaves during dry periods (Méndez-Toribio et al., 2020; Subedi et al., 2019). In later stages, canopy closure and biomass accumulation may somewhat buffer the adverse effects of seasonal drought on plant growth, allowing recruitment and species gains of large plants -especially those with slow or conservative strategies- even during the dry season. In agreement with our findings, Bretfeld et al. (2018) found a stronger response to an ENSO dry-season drought -with reductions in water-use to avoid hydraulic failure- in earlysuccessional compared to late-successional SDTF stands in Panama.

Peer) reviewing PDF | (2020:01:44799:1:2:NEW 20 Jun 2020) 
365 The combination of high recruitment and species gain rates with low mortality and species loss

366

367

368

369

370

371

372

373

374

375

376

377

378

379

380

381

382

383

384

385

386

387

388

389

390

391

392

393

394

395

396

397

398

399

400

401

402

403

rates early in succession resulted in a fast increase in large-size plant and species density. Sixty six percent of large-size plants (287 out of 425 ) that recruited during the study period were recorded in early successional plots. In contrast, only $3 \%$ (4 out of 133) of the large-size plants that died during the study period did so during early succession. Recruitment in early successional plots was dominated by pioneer species, such as Leucaena leucocephala (Fabaceae), Mimosa bahamensis (Fabaceae), Heliocarpus donnellsmithii (Malvaceae) and Cochlospermum vitifolium (Bixaceae), and by generalist species, such as Piscidia piscipula (Fabaceae) and Bursera simaruba (Burseraceae). These six species combined accounted for 74 $\%$ of all recruits in early-successional plots.

Our prediction (P4) that large plants would show low values of all demographic rates (recruitment, species gain, mortality and species loss) at intermediate and advanced successional stages was partly supported. Species gain and loss rates of large plants were indeed low at the intermediate and advanced successional stages (Figures $3 \mathrm{e}, \mathrm{f} ; 4 \mathrm{e}, \mathrm{f}$ ), resulting in fairly stable species densities (Figure $2 \mathrm{e}, \mathrm{f}$ ). However, compared to the other successional stages, mortality of large plants was higher at the intermediate stage, especially during the wet season (Figure 4 b), accounting for $62 \%$ of all large plants that died in this study. This roughly coincides with the timing of peak mortality found by Lebrija-Trejos et al. (2010a) in a SDTF in Oaxaca, Mexico: 15 to 18 years after abandonment, compared to 18 to 20 years in this study. These authors attributed this peak mortality (and a concomitant decline in the dominance of pioneer species) to competition within this guild -rather than competition with the mature forest guild. Canopy closure and the structural recovery of vegetation along succession are expected to increase the influence of competition and density-dependent processes on plant dynamics (Callaway, 1997; Bhaskar et al., 2014; Sanaphre-Villanueva et al., 2017; Dalmaso et al., 2019). The higher mortality of large plants at the intermediate successional stage may thus be associated with competition and density-dependent processes (Niinemets, 2010; Sanaphre-Villanueva et al., 2016).

In our study site, three early-successional species, Neomillspaughia emarginata (Polygonaceae), Mimosa bahamensis and Bauhinia ungulata (Fabaceae), together accounted for $63 \%$ of all deaths recorded in intermediate successional plots. These combined results suggest that our intermediate successional stage may correspond to the stand exclusion stage, characterized by self-thinning of the dominant pioneer species (Chazdon, 2008; Chazdon, 2014). However, in our site, these dominant early-successional species did not show a sharp decline at the intermediate and advanced stages, due to their continued recruitment (i.e. growth of previously established seedlings and saplings), which partially compensated for their high mortality. In particular, sprouting may be an important mechanism allowing these species to persist through succession (Dupuy et al., 2012).

The higher mortality of large plants observed in the wet compared to the dry season at the intermediate successional stage was unexpected, since drought during the dry season has been

Peer) reviewing PDF | (2020:01:44799:1:2:NEW 20 Jun 2020) 
404 associated with reduced growth and increased plant mortality (Swaine et al., 1990; Lieberman \& 405 Li, 1992; Gerhardt, 1993; Ceccon et al., 2006; Campos et al., 2019; Marques et al., 2020). Leaf 406 fall reduces the ability to unequivocally identify plant mortality during the dry period. In other 407 words, during the dry season, it is difficult to determine whether a plant is actually dead, since 408 drought-deciduous plants may appear dead but flush new leaves in the following wet season. To 409 control for this possibility, we conducted a separate analysis of large-plant mortality only for evergreen species -for which dry-season mortality can be more confidently determined. We found similar patterns and the same qualitative results shown by all large-size plants (Figures 4 a-c, S2 a-c), suggesting that our results may not be attributed to a sampling bias.

413 In a SDTF in Jalisco, Mexico, Maza-Villalobos et al. (2013) found higher mortality of seedlings in the wet than in the dry season. Noy-Meir (1974) first proposed the pulse-reserve paradigm for arid and semi-arid environments, where resources such as water and nutrients are available during pulses and unavailable during the interpulses, when plants adapted to these environments survive on carbon and water reserves. Goldberg \& Novoplansky (1997) proposed that, in productive environments, competition would be the most important factor limiting species persistence, while in environments with low productivity and prolonged interpulses, survival during interpulses would drive species persistence. Our results suggest that the community dynamics in the SDTF of our study are driven mostly by competition during pulses (wet seasons). Nevertheless, the interpulse (dry season) may still play a role in plant mortality; first, plants may reduce or deplete non-structural carbohydrates during the dry season to withstand drought (Amthor \& McCree, 1990; Myers \& Kitajima, 2007), which may lead to increased mortality in subsequent rainy seasons. Moreover, with the onset of rain, plants have to invest significant carbon reserves to produce new leaves (deciduous species) or repair damaged structures such as the photosynthetic apparatus (evergreen species) further depleting nonstructural carbohydrates (Schwinning \& Weiner, 1998; Reyes-García \& Griffiths, 2009). Second, reduced or depleted reserves may render plants more vulnerable to biotic stress from herbivores and pathogens or from shading and root competition -all of which peak during the rainy season (Filip et al., 1995; Cuevas-Reyes et al., 2006; Anderegg \& Callaway, 2012). This may jeopardize the capacity to keep a positive carbon balance to maintain plant respiration and growth, resulting in death. The duration and intensity of pulses and interpulses in water and nutrient availability will likely be affected by climate change through shifts in rainfall patterns, such as increases in the duration and severity of dry-season drought (interpulse), or reductions in the amount of rainy season precipitation (pulse) -Allen et al., 2017; Stan \& Sanchez-Azofeifa, 2019. Although our study is admittedly too short to draw any conclusions, our results suggest that successional dynamics in our study forest may be as (or even more) strongly influenced by climate-change driven decreases in wet season rainfall as (than) prolonged or severe droughts during the dry season.

441 Our prediction (P2) that small plant density would increase early in succession and subsequently 442 decline, whereas species density would stabilize following an initial increase was partly 443 supported by our results. Small plant density declined steadily not only at the intermediate- and 
444 advanced stages, but also at the early successional one, after only 5 years of land abandonment

445 (Figure 2 g-i). This steady decline in small plant density after such short abandonment period,

446 coupled with the opposite successional patterns of density of small (decreasing) vs. large

447 (increasing) plants, suggest a potential role of competition amongst small plants -early in

448 succession - as well as with larger plants -at intermediate- and advanced successional stages

449 (Niinemets, 2010; Sanaphre-Villanueva et al., 2016). A previous study in the same study region

450 also found opposite successional patterns of density for small vs. large plants and suggested size-

451 asymmetric competition as a potential cause (Dupuy et al., 2012).

452 We found only partial support for our prediction (P5) that, at intermediate and advanced

453 successional stages, mortality of small plants would be high and recruitment low, leading to a

454 decline in density, whereas species gain and loss rates would be generally low, thereby

455 stabilizing species density after an early-successional increase. Recruitment of small plants was

456 low and did not vary over succession (Figure $3 \mathrm{~g}-\mathrm{i}$ ), while mortality was slightly higher at the

457 advanced successional stage (Figure 4 g-i). Dalmaso et al. (2019) also found a net negative

458 balance between recruitment and mortality leading to a reduction in plant density in advanced

459 successional stages of a Brazilian Atlantic forest, likely reflecting intense competition. In our

460 study, small plant density declined steadily after only 5 years of land abandonment (Figure 2 g-

461 i), implying a fairly constant negative balance between recruitment and mortality in all

462 successional stages, as also found in other Mexican SDTF (Maza-Villalobos et al., 2011). Since

463 plant size increases over succession and small plants dominate density patterns (Dupuy et al.,

464 2012), our results indicate that overall plant density peaks very early in succession, creating a

465 short, dense, fairly uniform canopy. This may attenuate the effect of drought, which could help

466 explain the generally low dry season mortality rates observed in this study. A recent long-term

467 study in European temperate forest showed that increasing canopy cover can reduce warming

468 rates inside forests and can decouple local interior (microclimatic) conditions from regional

469 (macroclimatic) ones outside forests, thereby buffering against global warming (Zellweger et al.,

470 2020). On the other hand, canopy closure may also increase the influence of competition and

471 density-dependent processes on plant dynamics (Callaway, 1997; Bhaskar et al., 2014; Sanaphre-

472 Villanueva et al., 2017). Thus, the slightly higher mortality of small plants at the advanced

473 successional stage may be associated with competition and density-dependent processes

474 (Niinemets, 2010; Dalmaso et al. 2019).

475 The absence of significant differences in species gain or loss rates of small plants among

476 successional stages coupled with the increase in species density with successional stage imply a

477 positive balance between species gain and loss rates. The increase in species density of small

478 plants is in line with previous findings that species density increases along SDTF succession

479 (Guariguata \& Ostertag, 2001; Ruiz et al., 2005; Lebrija-Trejos et al., 2008; Dupuy et al., 2012).

480 This increase in species density, however, contrasts with the decrease in small plant density

481 across succession. These contrasting patterns are consistent with a strong dominance of the small

482 plant community by a few species with very high abundance early in succession, and a

483 subsequent decline in dominance (and density), allowing other species to colonize and increase 
484 species density. Only three pioneer species (N. emarginata, M. bahamensis and Helicteres 485 baruensis -Malvaceae-) accounted for almost $60 \%$ of total abundance in the early successional 486 stage. In the late successional stage, the small plant community showed lower dominance by a 487 mix of generalist species (Eugenia axillaris -Myrtaceae-, Guettarda gaumeri-Rubiaceae-) and 488 late-successional ones (Psidium sartorianum -Myrtaceae-, Amphilophium paniculatum and 489 Bignonia neoheterophylla-Bignoniaceae-), which together accounted for $44 \%$ of total

490

491

492

493

494

495

496

497

498

499

500

501

502

503

504

505

506

507

508

509

510

511

512

513

514

515

516

517

518

519

520

521

522

523 abundance. Dupuy et al. (2012) also documented a general decline in woody plant density and species dominance coupled with an overall increase in plant species richness across forest succession in the same study region.

The effects of seasonality, successional stage and their change over time were more apparent on large-size plants than on small-size ones (Figures 2-4). This result was somewhat unexpected, since small plants have smaller root and shoot systems to capture resources and store carbon and water, and therefore were expected to be more vulnerable to seasonal drought and more dependent on seasonal water availability for recruitment and growth than large plants (Kitajima \& Fenner, 2000; Quitete-Portela \& Maës dos Santos, 2009). It is likely that the large among-plot variation shown by small plants, coupled with strong annual variation in rainfall (Figure S1) obscured the effects of seasonality, successional stage and time. It is also possible that the strongest successional and seasonal-drought filters occur in plants smaller (i.e. dbh $<1 \mathrm{~cm}$ ) than those included in this study. In our study forest, Jackson et al. (2018) described strategies for the survival of small trees, such as deep roots, osmotic adjustment and tight stomatal control.

Alternatively, recruitment, mortality and species gain and loss rates of small plants could be more strongly influenced by other factors that may confound the effects of seasonality and successional stage. For example, compared to larger plants, dispersal limitation can be expected to have a greater influence on small plants (in earlier stages of plant ontogeny) thereby potentially increasing random among-plot variation. The consistently lower values of marginal variance $\left(R^{2} m\right)$-explained by fixed effects only- and the generally greater relative difference between conditional $\left(R^{2} c\right)$ and marginal variance -indicating the importance of random effectsfound for small plants compared to large ones (Tables S2-S7) are consistent with this interpretation. Alternatively, local site factors, such as con-specific density, the spatial distribution of neighboring plants or the identity of the dominant species may alter biotic interactions (e.g. competition, herbivory) and/or abiotic conditions (e.g. light and water availability) and thereby affect the demographic rates of small plants (Granda et al., 2014; Mesquita et al., 2015; Espinosa et al., 2016; Ma et al., 2016), which may be particularly sensitive to such local factors. Recent studies show that interactions among multiple sources of environmental stress (climatic and soil variables) play a key role in plant species filtering -which may be expected to have a greater impact on small than on large plants- in dry forests (Bagousse-Pinguet et al., 2017; Méndez-Toribio et al., 2020). Further studies are needed to elucidate the complexity of ecological factors and plant strategies that influence plant and species density as well as seasonal and successional size-dependent dynamics and demographic rates in SDTF. 
524

525

526

527

528

529

530

531

532

533

534

535

536

537

538

539

540

541

542

543

544

545

546

547

548

549

550

551

552

553

554

555

556

557

558

559

560

561

562

\section{Conclusions}

As hypothesized, we found marked differences in demographic rates and in plant and species density between large- and small-size plants across succession, between seasons and over the study period. Clear trends in how these attributes changed across years, seasons, and successional stages were more apparent for large than for small plants. Small plant density decreased steadily after only 5 years of land abandonment, whereas species density increased with successional stage, likely reflecting a decline in species dominance. Overall, we found no clear successional, interannual or seasonal trends in small plant demographic rates likely due to large random among-plot variation. In contrast, seasonality affected demographic rates and density of large plants, which exhibited high wet-season recruitment and species gain rates at the early stage coupled with high wet-season mortality at the intermediate stage, resulting in the predicted increase in plant and species density early in succession and subsequent stabilization. Notwithstanding the short duration of our study, our results suggest that a climate change-driven decrease in rainy season rainfall may have an influence on successional dynamics (and hence resilience) in our study forest as strong as, or even stronger than, prolonged or severe droughts during the dry season.

\section{Acknowledgements}

We thank James Callaghan and Kaxil Kiuic A.C. for the facilities and support provided, and the local inhabitants of Xkobenhaltun for their continued help with fieldwork.

\section{References}

Aide TM, Clark ML, Grau HR, López-Carr D, Levy MA, Redo D, Bonilla-Moheno M, Riner G, Andrade-Núñez MJ, and Muñiz M. 2013. Deforestation and Reforestation of Latin America and the Caribbean (2001-2010). Biotropica 45:262-271 DOI 10.1111/j.17447429.2012.00908.x

Aide TM, Zimmerman JK, Pascarella JB, Rivera L, and Marcano-Vega H. 2000. Forest Regeneration in a Chronosequence of Tropical Abandoned Pastures: Implications for Restoration Ecology. Restoration Ecology 8:328-338 DOI 10.1046/j.1526100x.2000.80048.x

Alberton B, da Silva Torres R, Sanna Freire Silva T, Rocha HR, SB Moura M, and Morellato LPC. 2019. Leafing patterns and drivers across seasonally dry tropical communities. Remote Sensing 11:2267 DOI 10.3390/rs11192267

Allen K, Dupuy JM, Gei MG, Hulshof C, Medvigy D, Pizano C, Salgado-Negret B, Smith CM, Trierweiler A, Van Bloem SJ, Waring BG, Xu X, and Powers JS. 2017. Will seasonally 
563

564

565

566

567

568

569

570

571

572

573

574

575

576

577

578

579

580

581

582

583

584

585

586

587

588

589

590

591

592

593

594

595

596

597

598

dry tropical forests be sensitive or resistant to future changes in rainfall regimes? Environmental Research Letters 12:023001 DOI 10.1088/1748-9326/aa5968

Amthor J, and McCree KJ. 1990. Carbon balance of stressed plants: a conceptual model for integrating research results. In: Alscher RG, and Cumming JR, eds. Stress Responses in Plants: Adaptation and Acclimation Mechanisms. New York: Wiley-Liss, Inc., 1-15.

Anderegg WRL, and Callaway ES. 2012. Infestation and Hydraulic Consequences of Induced Carbon Starvation. Plant Physiology 159:1866-1874 DOI 10.1104/pp.112.198424

Bagousse-Pinguet YL, Gross N, Maestre FT, Maire V, de Bello F, Fonseca CR, Kattge J, Valencia E, Leps J and Liancourt P. 2017. Testing the environmental filtering concept in global drylands. Journal of Ecology, 105:1058-1069 DOI 10.1111/ijlh.12426

Bartoń K. 2018. MuMIn: Multi-model Inference. R Package version 1.40.4.

Bates D, Mächler M, Bolker B, and Walker S. 2015. Fitting Linear Mixed-Effects Models Using lme4. Journal of Statistical Software 67:48 DOI 10.18637/jss.v067.i01

Becknell JM, Kissing Kucek L, and Powers JS. 2012. Aboveground biomass in mature and secondary seasonally dry tropical forests: A literature review and global synthesis. Forest Ecology and Management 276:88-95 DOI 10.1016/j.foreco.2012.03.033

Bhaskar R, Dawson TE, and Balvanera P. 2014. Community assembly and functional diversity along succession post-management. Functional Ecology 28:1256-1265 DOI 10.1111/13652435.12257

Bretfeld M, Ewers BE, and Hall JS. 2018. Plant water use responses along secondary forest succession during the 2015-2016 El Niño drought in Panama. New Phytologist 219:885899 DOI 10.1111/nph.15071

Brum M, Vadeboncoeur MA, Ivanov V, Asbjornsen H, Saleska S, Alves LF, Penha D, Dias JD, Aragão LEOC, Barros F, Bittencourt P, Pereira L, and Oliveira RS. 2019. Hydrological niche segregation defines forest structure and drought tolerance strategies in a seasonal Amazon forest. Journal of Ecology 107:318-333 DOI 10.1111/1365-2745.13022

Cach-Pérez MJ, Andrade JL, and Reyes-García C. 2018. Morphophysiological Plasticity in Epiphytic Bromeliads Across a Precipitation Gradient in the Yucatan Peninsula, Mexico. Tropical Conservation Science 11 DOI 10.1177/1940082918781926

Callaway RM. 1997. Positive interactions in plant communities and the individualisticcontinuum concept. Oecologia 112:143-149 DOI 10.1007/s004420050293

Campos S, Mendes KR, da Silva LL, Mutti PR, Medeiros SS, Amorim LB, dos Santos CAC, Perez-Marin AM, Ramos TM, Marques TV, Lucio PS, Costa GB, e Silva CMS and Bezerra BG. 2019. Closure and partitioning of the energy balance in a preserved area of a Brazilian seasonally dry tropical forest, Agricultural and Forest Meteorology 271:398-412 DOI 10.1016/j.agrformet.2019.03.018 
599 Capers RS, Chazdon RL, Brenes AR, and Alvarado BV. 2005. Successional dynamics of woody

600

601

602

603

604

605

606

607

608

609

610

611

612

613

614

615

616

617

618

619

620

621

622

623

624

625

626

627

628

629

630

631

632

633

634

635

seedling communities in wet tropical secondary forests. Journal of Ecology 93:1071-1084 DOI $10.1111 / \mathrm{j} .1365-2745.2005 .01050 . \mathrm{x}$

Ceccon E, Huante P, and Rincón E. 2006. Abiotic Factors Influencing Tropical Dry Forests Regeneration. Brazilian Archives of Biology and Technology 49:305-312 DOI 10.1590/S1516-89132006000300016

Cuevas-Reyes P, Quesada M, and Oyama K. 2006. Abundance and Leaf Damage Caused by Gall-Inducing Insects in a Mexican Tropical Dry Forest. Biotropica 38:107-115 DOI 10.1111/j.1744-7429.2006.00115.x

Chazdon. 2008. Chance and Determinism in Tropical Forest Succession. In: Carson W, and Schnitzer S, eds. Tropical forest community ecology. Oxford, UK: Wiley - Blackwell Publishing, 385-408.

Chazdon, Letcher SG, van Breugel M, Martínez-Ramos M, Bongers F, and Finegan B. 2007. Rates of change in tree communities of secondary Neotropical forests following major disturbances. Philosophical transactions of the Royal Society of London Series B, Biological sciences 362:273-289 DOI 10.1098/rstb.2006.1990

Chazdon R. 2014. Second growth: the promise of tropical forest regeneration in an age of deforestation. Chicago: University of Chicago Press.

Chazdon R, Harvey Ca, Martínez-Ramos M, Balvanera P, Stoner KE, Schondube JE, AvilaCabadilla LD, and Flores-Hidalgo M. 2011. Seasonally dry tropical forests: ecology and conservation. In: Dirzo R, Young HS, Mooney HA, and Ceballos G, eds. Seasonally Dry Tropical Forests ecology and conservation. U.S.A: Island Press.

Chazdon RL, Broadbent EN, Rozendaal DMA, Bongers F, Zambrano AMA, Aide TM, Balvanera P, Becknell JM, Boukili V, Brancalion PHS, Craven D, Almeida-Cortez JS, Cabral GAL, de Jong B, Denslow JS, Dent DH, DeWalt SJ, Dupuy JM, Durán SM, Espírito-Santo MM, Fandino MC, César RG, Hall JS, Hernández-Stefanoni JL, Jakovac CC, Junqueira AB, Kennard D, Letcher SG, Lohbeck M, Martínez-Ramos M, Massoca P, Meave JA, Mesquita R, Mora F, Muñoz R, Muscarella R, Nunes YRF, Ochoa-Gaona S, Orihuela-Belmonte E, Peña-Claros M, Pérez-García EA, Piotto D, Powers JS, RodríguezVelazquez J, Romero-Pérez IE, Ruíz J, Saldarriaga JG, Sanchez-Azofeifa A, Schwartz NB, Steininger MK, Swenson NG, Uriarte M, van Breugel M, van der Wal H, Veloso MDM, Vester H, Vieira ICG, Bentos TV, Williamson GB, and Poorter L. 2016. Carbon sequestration potential of second-growth forest regeneration in the Latin American tropics. Science Advances 2:e1501639 DOI 10.1126/sciadv.1501639

Dalmaso CA, Marques MCM, Higuchi P, Zwiener VP, Marques R. 2020. Spatial and temporal structure of diversity and demographic dynamics along a successional gradient of tropical forests in southern Brazil. Ecology and Evolution 10:3164-3177 DOI 10.1002/ece3.5816

Peer) reviewing PDF | (2020:01:44799:1:2:NEW 20 Jun 2020) 
636 Denslow JS. 1995. Disturbance and Diversity in Tropical Rain Forests: The Density Effect.

637

638

639

640

641

642

643

644

645

646

647

648

649

650

651

652

653

654

655

656

657

658

659

660

661

662

663

664

665

666

667

668

669

670

671 Ecological Applications 5:962-968 DOI 10.2307/2269347

Derroire G, Balvanera P, Castellanos-Castro C, Decocq G, Kennard DK, Lebrija-Trejos E, Leiva JA, Odén P-C, Powers JS, Rico-Gray V, Tigabu M, and Healey JR. 2016. Resilience of tropical dry forests - a meta-analysis of changes in species diversity and composition during secondary succession. Oikos 125:1386-1397 DOI 10.1111/oik.03229

Dirzo R, Young HS, Mooney HA, and Ceballos G. 2011. Seasonally dry tropical forests: ecology and conservation. Washington: Island Press.

Dupuy JM, Hernández-Stefanoni JL, Hernandez-Juárez RA, Tetetla-Rangel E, López-Martínez JO, Leyequién-Abarca E, Tun-Dzul FJ, and May-Pat F. 2012. Patterns and Correlates of Tropical Dry Forest Structure and Composition in a Highly Replicated Chronosequence in Yucatan, Mexico. Biotropica 44:151-162 DOI 10.1111/j.1744-7429.2011.00783.x

Espinosa CI, de la Cruz M, Jara-Guerrero A, Gusmán E, and Escudero A. 2016. The effects of individual tree species on species diversity in a tropical dry forest change throughout ontogeny. Ecography 39:329-337 DOI 10.1111/ecog.01328

FAO. 2015. Global Forest Resources Assessment 2015. How Are the World's Forests Changing? Rome, Italy: Food and Agriculture Organization of the United Nations (FAO).

Filip V, Dirzo R, Maass JM, and Sarukhan J. 1995. Within- and Among-Year Variation in the Levels of Herbivory on the Foliage of Trees from a Mexican Tropical Deciduous Forest. Biotropica 27:78-86 DOI 10.2307/2388905

Gaviria J, and Engelbrecht BMJ. 2015. Effects of Drought, Pest Pressure and Light Availability on Seedling Establishment and Growth: Their Role for Distribution of Tree Species across a Tropical Rainfall Gradient. Plos One 10:e0143955 DOI 10.1371/journal.pone.0143955

Gerhardt K. 1993. Tree Seedling Development in Tropical Dry Abandoned Pasture and Secondary Forest in Costa Rica. Journal of Vegetation Science 4:95-102 DOI $10.2307 / 3235736$

Goldberg D, and Novoplansky A. 1997. On the Relative Importance of Competition in Unproductive Environments. Journal of Ecology 85:409-418 DOI 10.2307/2960565

González-Cruz G, García-Frapolli E, Casas Fernández A, Dupuy-Rada JM. 2015. Responding to disturbances: lessons from a Mayan social-ecological system. International Journal of the Commons 9: 831-850.Granda E, Escudero A, and Valladares F. 2014. More than just drought: complexity of recruitment patterns in Mediterranean forests. Oecologia 176:9971007 DOI 10.1007/s00442-014-3064-x

Guariguata MR, and Ostertag R. 2001. Neotropical secondary forest succession: changes in structural and functional characteristics. Forest Ecology and Management 148:185-206 DOI 10.1016/S0378-1127(00)00535-1 
672 Gunn CM. 2015. Exchange mechanisms, consumption, and household provisioning strategies:

673

674

675

676

677

678

679

680

681

682

683

684

685

686

687

688

689

690

691

692

693

694

695

696

697

698

699

700

701

702

703

704

705 maya economy and political economy in the Kiuic polity, Yucatán, México Doctor of Philosophy Thesis. University of Kentucky.

Harms KE, Wright SJ, Calderón O, Hernández A, and Herre EA. 2000. Pervasive densitydependent recruitment enhances seedling diversity in a tropical forest. Nature 404:493-495 DOI $10.1038 / 35006630$

Holbrook NM, Whitbeck JL, and Mooney HA. 1995. Drought responses of neotropical dry forest trees. In: Bullock SH, Mooney HA, and Medina E, eds. Seasonally Dry Tropical Forests. Cambridge: Cambridge University Press, 243-270.

Jackson P, Andrade J, Reyes-García C, Hernández-González O, McElroy T, Us-Santamaría R, Simá J, and Dupuy J. 2018. Physiological Responses of Species to Microclimate Help explain Population Dynamics along Succession in a Tropical Dry Forest of Yucatan, Mexico. Forests 9:411 DOI 10.3390/f9070411

Janzen D. 1988. Tropical dry forests. The most endangered major tropical ecosystem. In: Wilson EO, ed. Biodiversity. Washington: National Academy of Sciences/Smithsonian Institution, $130-137$.

Kennard DK. 2002. Secondary forest succession in a tropical dry forest: patterns of development across a 50-year chronosequence in lowland Bolivia. Journal of Tropical Ecology 18:53-66 DOI 10.1017/s0266467402002031

Khurana E, and Singh JS. 2001. Ecology of tree seed and seedlings: Implications for tropical forest conservation and restoration. Current Science 80:748-757 DOI https://www.jstor.org/stable/24105660

Kitajima K, and Fenner M. 2000. Ecology of Seedling Regeneration. In: Fenner M, ed. Seeds : the ecology of regeneration in plant communities. London: Biddles Ltd, Guildford and King's Lynn, 397.

Lara Ponce E, Caso Barrera L, and Aliphat Fernández M. 2012. El sistema de milpa roza, tumba y quema de los maya itzá de San Andrés y San José, Petén Guatemala. Ra Ximhai 8:71-92

Lebrija-Trejos E, Bongers F, Pérez-García EA, and Meave JA. 2008. Successional Change and Resilience of a Very Dry Tropical Deciduous Forest Following Shifting Agriculture. Biotropica 40:422-431 DOI 10.1111/j.1744-7429.2008.00398.x

Lebrija-Trejos E, Meave JA, Poorter L, Pérez-García EA, and Bongers F. 2010a. Pathways, mechanisms and predictability of vegetation change during tropical dry forest succession. Perspectives in Plant Ecology, Evolution and Systematics 12:267-275 DOI 10.1016/j.ppees.2010.09.002 
706

707

708

709

710

711

712

713

714

715

716

717

718

719

720

721

722

723

724

725

726

727

728

729

730

731

732

733

734

735

736

737

738

739

740

Lebrija-Trejos E, Pérez-García EA, Meave JA, Bongers F, and Poorter L. 2010b. Functional traits and environmental filtering drive community assembly in a species-rich tropical system. Ecology 91:386-398 DOI 10.1890/08-1449.1

Lebrija-Trejos E, Pérez-García EA, Meave JA, Poorter L, and Bongers F. 2011. Environmental changes during secondary succession in a tropical dry forest in Mexico. Journal of Tropical Ecology 27:477-489 DOI 10.1017/S0266467411000253

Lieberman D, and Li M. 1992. Seedling recruitment patterns in a tropical dry forest in Ghana. Journal of Vegetation Science 3:375-382 DOI 10.2307/3235763

Ma L, Lian J, Lin G, Cao H, Huang Z, and Guan D. 2016. Forest dynamics and its driving forces of sub-tropical forest in South China. Scientific Reports 6:22561 DOI 10.1038/srep22561

Marques TV, Mendes K, Mutti P, Medeiros S, Silva L, Perez-Marin AM, Campos S, Lúcio PS, Lima K, dos Reis J, Ramos TM, da Silva DF, Oliveira CP, Costa GB, Antonino ACD, Menezes RSC, Santos e Silva CM, and Bezerra B. 2020. Environmental and biophysical controls of evapotranspiration from Seasonally Dry Tropical Forests (Caatinga) in the Brazilian Semiarid. Agricultural and Forest Meteorology 287:107957 DOI 10.1016/j.agrformet.2020.107957

Martínez-Ramos M, Balvanera P, Arreola Villa F, Mora F, Maass JM, and Maza-Villalobos Méndez S. 2018. Effects of long-term inter-annual rainfall variation on the dynamics of regenerative communities during the old-field succession of a neotropical dry forest. Forest Ecology and Maovdsnagement 426:91-100 DOI 10.1016/j.foreco.2018.04.048

Maza-Villalobos S, Balvanera P, and Martínez-Ramos M. 2011. Early Regeneration of Tropical Dry Forest from Abandoned Pastures: Contrasting Chronosequence and Dynamic Approaches. Biotropica 43:666-675 DOI 10.1111/j.1744-7429.2011.00755.x

Maza-Villalobos S, Poorter L, and Martínez-Ramos M. 2013. Effects of ENSO and Temporal Rainfall Variation on the Dynamics of Successional Communities in Old-Field Succession of a Tropical Dry Forest. Plos One 8:1-12 DOI 10.1371/journal.pone.0082040

McLaren KP, and McDonald MA. 2003. The effects of moisture and shade on seed germination and seedling survival in a tropical dry forest in Jamaica. Forest Ecology and Management 83:61-75 DOI 10.1016/S0378-1127(03)00100-2

Méndez-Alonzo R, Pineda-García F, Paz H, Rosell JA, and Olson ME. 2013. Leaf phenology is associated with soil water availability and xylem traits in a tropical dry forest. Trees 27:745-754 DOI 10.1007/s00468-012-0829-x

Méndez-Toribio M, Ibarra-Manríquez G, Paz H, and Lebrija-Trejos E. 2020. Atmospheric and soil drought risks combined shape community assembly of trees in a tropical dry forest. Journal of Ecology 00: 1-11 DOI 10.1111/1365-2745.13355 
741 Mesquita RCG, Ickes K, Ganade G, and Williamson GB. 2001. Alternative successional

742

743

744

745

746

747

748

749

750

751

752

753

754

755

756

757

758

759

760

761

762

763

764

765

766

767

768

769

770

771

772

773

774 pathways in the Amazon Basin. Journal of Ecology 89:528-537 DOI 10.1046/j.13652745.2001.00583.x

Mesquita RdCG, Massoca PEdS, Jakovac CC, Bentos TV, and Williamson GB. 2015. Amazon Rain Forest Succession: Stochasticity or Land-Use Legacy? BioScience 65:849-861 DOI 10.1093/biosci/biv108

Miles L, Newton AC, DeFries RS, Ravilious C, May I, Blyth S, Kapos V, and Gordon JE. 2006. A global overview of the conservation status of tropical dry forests. Journal of Biogeography 33:491-505 DOI 10.1111/j.1365-2699.2005.01424.x

Murphy PG, and Lugo AE. 1986. Ecology of Tropical Dry Forest. Annual Review of Ecology and Systematics 17:67-88 DOI 10.1146/annurev.es.17.110186.000435

Muscarella R, Lohbeck M, Martínez-Ramos M, Poorter L, Rodríguez-Velázquez JE, van Breugel M, and Bongers F. 2017. Demographic drivers of functional composition dynamics. Ecology 98:2743-2750 DOI 10.1002/ecy.1990

Myers JA, and Kitajima K. 2007. Carbohydrate storage enhances seedling shade and stress tolerance in a neotropical forest. Journal of Ecology 95:383-395 DOI 10.1111/j.13652745.2006.01207.x

Nakagawa S, and Schielzeth H. 2013. A general and simple method for obtaining R2 from generalized linear mixed-effects models. Methods in Ecology and Evolution 4:133-142 DOI doi:10.1111/j.2041-210x.2012.00261.x

Niinemets Ü. 2010. Responses of forest trees to single and multiple environmental stresses from seedlings to mature plants: Past stress history, stress interactions, tolerance and acclimation. Forest Ecology and Management 260:1623-1639 DOI 10.1016/j.foreco.2010.07.054

Noy-Meir I. 1974. Desert Ecosystems: Higher Trophic Levels. Annual Review of Ecology and Systematics 5:195-214 DOI 10.1146/annurev.es.05.110174.001211

Orellana R, Balam M, Bañuelos I, García E, González-Iturbe JA, Cetina FH, and López JV. 1999. Evaluación Climática. In: García de Fuentes A, Córdoba y Ordoñez J, and Chico Ponce de León P, eds. Atlas de Procesos Territorales de Yucatán. Mérida, México: Universidad Autónoma de Yucatán, 161-182.

Pan Y, Birdsey RA, Fang J, Houghton R, Kauppi PE, Kurz WA, Phillips OL, Shvidenko A, Lewis SL, Canadell JG, Ciais P, Jackson RB, Pacala SW, McGuire AD, Piao S, Rautiainen A, Sitch S, and Hayes D. 2011. A Large and Persistent Carbon Sink in the World's Forests. Science 333:988-993 DOI 10.1126/science.1201609

Peer] reviewing PDF | (2020:01:44799:1:2:NEW 20 Jun 2020) 
775 Peel MC, Finlayson BL, and McMahon TA. 2007. Updated world map of the Köppen-Geiger

776

777

778

779

780

781

782

783

784

785

786

787

788

789

790

791

792

793

794

795

796

797

798

799

800

801

802

803

804

805

806

807

808

809

810

811

812 climate classification. Hydrol Earth Syst Sci 11:1633-1644 DOI 10.5194/hess-11-16332007

Pineda-García F, Paz H, and Meinzer FC. 2013. Drought resistance in early and late secondary successional species from a tropical dry forest: the interplay between xylem resistance to embolism, sapwood water storage and leaf shedding. Plant, Cell and Environment 36:405-418 DOI 10.1111/j.1365-3040.2012.02582.x

Poorter L, Bongers F, Aide MT, Zambrano AM, Balvanera P, Becknell JM, Boukili V, Brancalion PHS, Broadbent EN, Chazdon RL, Craven D, de Almeida-Cortez JS, Cabral GAL, de Jong BHJ, Denslow JS, Dent DH, DeWalt SJ, Dupuy JM, Durán SM, EspíritoSanto MM, Fandino MC, César RG, Hall JS, Hernandez-Stefanoni J, Jakovac CC, Junqueira AB, Kennard D, Letcher SG, Licona J-C, Lohbeck M, Marín-Spiotta E, Martínez-Ramos M, Massoca P, Meave JA, Mesquita R, Mora F, Muñoz R, Muscarella R, Nunes YRF, Ochoa-Gaona S, de Oliveira AA, Orihuela-Belmonte E, Peña-Claros M, Pérez-García EA, Piotto D, Powers JS, Rodríguez-Velázquez J, Romero-Pérez EI, Ruíz J, Saldarriaga JG, Sanchez-Azofeifa A, Schwartz NB, Steininger MK, Swenson NG, Toledo M, Uriarte M, van Breugel M, van der Wal H, Veloso MDM, Vester HFM, Vicentini A, Vieira ICG, Bentos T, Williamson BG, and Rozendaal DMA. 2016. Biomass resilience of Neotropical secondary forests. Nature 530:211-214 DOI 10.1038/nature16512

Quitete-Portela RDC, and Maës dos Santos FA. 2009. Mortality and mechanical damage of seedlings in different size fragments of the Brazilian Atlantic Forest. Tropical Ecology 50:267-275

R Development Core Team. 2012. R: a language and environment for statistical computing. Vienna: R Foundation for Statistical Computing. Available at http://www.R-project.org.

Reyes-García C, and Griffiths H. 2009. Ecophysiological studies of perennials of the Bromeliaceae family in a dry forest: strategies for survival. In: De la Barrera E, ed. Perspectives in Biophysical Plant Ecophysiology A Tribute to Park S Nobel. México: Universidad Nacional Autónoma de México, 121-151.

Rico-Gray V, and García-Franco JG. 1991. The Maya and the vegetation of theYucatan Peninsula. Journal of Ethnobiology 11:135-142 DOI

Rozendaal DMA, Bongers F, Aide TM, Alvarez-Dávila E, Ascarrunz N, Balvanera P, Becknell JM, Bentos TV, Brancalion PHS, Cabral GAL, Calvo-Rodriguez S, Chave J, César RG, Chazdon RL, Condit R, Dallinga JS, de Almeida-Cortez JS, de Jong B, de Oliveira A, Denslow JS, Dent DH, DeWalt SJ, Dupuy JM, Durán SM, Dutrieux LP, Espírito-Santo MM, Fandino MC, Fernandes GW, Finegan B, García H, Gonzalez N, Moser VG, Hall JS, Hernández-Stefanoni JL, Hubbell S, Jakovac CC, Hernández AJ, Junqueira AB, Kennard D, Larpin D, Letcher SG, Licona J-C, Lebrija-Trejos E, Marín-Spiotta E, Martínez-Ramos M, Massoca PES, Meave JA, Mesquita RCG, Mora F, Müller SC, Muñoz R, de Oliveira 
813

814

815

816

817

818

819

820

821

822

823

824

825

826

827

828

829

830

831

832

833

834

835

836

837

838

839

840

841

842

843

844

845

846

847

848

Neto SN, Norden N, Nunes YRF, Ochoa-Gaona S, Ortiz-Malavassi E, Ostertag R, PeñaClaros M, Pérez-García EA, Piotto D, Powers JS, Aguilar-Cano J, Rodriguez-Buritica S, Rodríguez-Velázquez J, Romero-Romero MA, Ruíz J, Sanchez-Azofeifa A, de Almeida AS, Silver WL, Schwartz NB, Thomas WW, Toledo M, Uriarte M, de Sá Sampaio EV, van Breugel M, van der Wal H, Martins SV, Veloso MDM, Vester HFM, Vicentini A, Vieira ICG, Villa P, Williamson GB, Zanini KJ, Zimmerman J, and Poorter L. 2019. Biodiversity recovery of Neotropical secondary forests. Science Advances 5:eaau3114 DOI 10.1126/sciadv.aau3114

Rozendaal DMA, and Chazdon RL. 2015. Demographic drivers of tree biomass change during secondary succession in northeastern Costa Rica. Ecological Applications 25:506-516 DOI 10.1890/14-0054.1

Rozendaal DMA, Chazdon RL, Arreola-Villa F, Balvanera P, Bentos TV, Dupuy JM, Hernández-Stefanoni JL, Jakovac CC, Lebrija-Trejos EE, Lohbeck M, Martínez-Ramos M, Massoca PES, Meave JA, Mesquita RCG, Mora F, Pérez-García EA, Romero-Pérez IE, Saenz-Pedroza I, van Breugel M, Williamson GB, and Bongers F. 2017. Demographic Drivers of Aboveground Biomass Dynamics During Secondary Succession in Neotropical Dry and Wet Forests. Ecosystems 20:340-353 DOI 10.1007/s10021-016-0029-4

Ruiz J, Fandiño MC, and Chazdon RL. 2005. Vegetation Structure, Composition, and Species Richness Across a 56-year Chronosequence of Dry Tropical Forest on Providencia Island, Colombia. Biotropica 37:520-530 DOI 10.1111/j.1744-7429.2005.00070.x

Saatchi SS, Harris NL, Brown S, Lefsky M, Mitchard ETA, Salas W, Zutta BR, Buermann W, Lewis SL, Hagen S, Petrova S, White L, Silman M, and Morel A. 2011. Benchmark map of forest carbon stocks in tropical regions across three continents. Proceedings of the National Academy of Sciences of the United States of America 108:9899-9904 DOI 10.1073/pnas. 1019576108

Sanaphre-Villanueva L, Dupuy J, Andrade J, Reyes C, Paz H, and Jackson P. 2016. Functional Diversity of Small and Large Trees Along Secondary Succession in a Tropical Dry Forest. Forests 7:1-16 DOI 10.3390/f7080163

Sanaphre-Villanueva L, Dupuy JM, Andrade JL, Reyes-García C, Jackson PC, and Paz H. 2017. Patterns of plant functional variation and specialization along secondary succession and topography in a tropical dry forest. Environmental Research Letters 12:055004 DOI 10.1088/1748-9326/aa6baa

Sánchez-Azofeifa GA, and Portillo-Quintero C. 2011. Extent and Drivers of Change of Neotropical Seasonally Dry Tropical Forests. In: Dirzo R, Young HS, Mooney HA, and Ceballos G, eds. Seasonally Dry Tropical Forests: ecology and conservation. Washington: Island Press, 45-57. 
849 Schwinning S, and Weiner J. 1998. Mechanisms determining the degree of size asymmetry in competition among plants. Oecologia 113:447-455 DOI 10.1007/s004420050397

851

852

853

854

855

856

857

858

859

860

861

862

863

864

865

866

867

868

869

870

871

872

873

874

875

876

877

878

879

880

881

882

883

884

885

Slik JWF, Arroyo-Rodríguez V, Aiba S-I, Alvarez-Loayza P, Alves LF, Ashton P, Balvanera P, Bastian ML, Bellingham PJ, van den Berg E, Bernacci L, da Conceição Bispo P, Blanc L, Böhning-Gaese K, Boeckx P, Bongers F, Boyle B, Bradford M, Brearley FQ, BreuerNdoundou Hockemba M, Bunyavejchewin S, Calderado Leal Matos D, Castillo-Santiago M, Catharino ELM, Chai S-L, Chen Y, Colwell RK, Chazdon RL, Clark C, Clark DB, Clark DA, Culmsee H, Damas K, Dattaraja HS, Dauby G, Davidar P, DeWalt SJ, Doucet J-L, Duque A, Durigan G, Eichhorn KAO, Eisenlohr PV, Eler E, Ewango C, Farwig N, Feeley KJ, Ferreira L, Field R, de Oliveira Filho AT, Fletcher C, Forshed O, Franco G, Fredriksson G, Gillespie T, Gillet J-F, Amarnath G, Griffith DM, Grogan J, Gunatilleke N, Harris D, Harrison R, Hector A, Homeier J, Imai N, Itoh A, Jansen PA, Joly CA, de Jong BHJ, Kartawinata K, Kearsley E, Kelly DL, Kenfack D, Kessler M, Kitayama K, Kooyman R, Larney E, Laumonier Y, Laurance S, Laurance WF, Lawes MJ, Amaral ILd, Letcher SG, Lindsell J, Lu X, Mansor A, Marjokorpi A, Martin EH, Meilby H, Melo FPL, Metcalfe DJ, Medjibe VP, Metzger JP, Millet J, Mohandass D, Montero JC, de Morisson Valeriano M, Mugerwa B, Nagamasu H, Nilus R, Ochoa-Gaona S, Onrizal, Page N, Parolin P, Parren M, Parthasarathy N, Paudel E, Permana A, Piedade MTF, Pitman NCA, Poorter L, Poulsen AD, Poulsen J, Powers J, Prasad RC, Puyravaud J-P, Razafimahaimodison J-C, Reitsma J, dos Santos JR, Roberto Spironello W, Romero-Saltos H, Rovero F, Rozak AH, Ruokolainen K, Rutishauser E, Saiter F, Saner P, Santos BA, Santos F, Sarker SK, Satdichanh M, Schmitt CB, Schöngart J, Schulze M, Suganuma MS, Sheil D, da Silva Pinheiro E, Sist P, Stevart T, Sukumar R, Sun I-F, Sunderland T, Suresh HS, Suzuki E, Tabarelli M, Tang J, Targhetta N, Theilade I, Thomas DW, Tchouto P, Hurtado J, Valencia R, van Valkenburg JLCH, Van Do T, Vasquez R, Verbeeck H, Adekunle V, Vieira SA, Webb CO, Whitfeld T, Wich SA, Williams J, Wittmann F, Wöll H, Yang X, Adou Yao CY, Yap SL, Yoneda T, Zahawi RA, Zakaria R, Zang R, de Assis RL, Garcia Luize B, and Venticinque EM. 2015. An estimate of the number of tropical tree species. Proceedings of the National Academy of Sciences 112:7472-7477 DOI 10.1073/pnas. 1423147112

Stan K, and Sanchez-Azofeifa A. 2019. Tropical dry forest diversity, climatic response, and resilience in a changing climate. Forests 10: 443 DOI 10.3390/f10050443

Subedi SC, Ross MS, Sah JP, Redwine J, and Baraloto C. 2019. Trait-based community assembly pattern along a forest succession gradient in a seasonally dry tropical forest. Ecosphere, 10: e02719 DOI 10.1002/ecs2.2719

Swaine MD, Lieberman D, and Hall JB. 1990. Structure and dynamics of a tropical dry forest in Ghana. Vegetatio 88:31-51 DOI 10.1007/bf00032601 
886 van Breugel M, Martínez-Ramos M, and Bongers F. 2006. Community dynamics during early 887 secondary succession in Mexican tropical rain forests. Journal of Tropical Ecology $888 \quad 22: 663-674$ DOI $10.1017 /$ s0266467406003452

889 Webb CO, and Peart DR. 1999. Seedling Density Dependence Promotes Coexistence of Bornean 890 Rain Forest Trees. Ecology 80:2006-2017 DOI 10.2307/176674

891 Zellweger F, De Frenne P, Lenoir J, Vangansbeke P, Verheyen K, Bernhardt-Römermann M, 892 Baeten L, Hédl R, Berki I, Brunet J, Van Calster H, Chudomelová M, Decocq G, Dirnböck 893 T, Durak T, Heinken T, Jaroszewicz B, Kopecký M, Máliš F, Macek M, Malicki M, Naaf 894 T, Nagel TA, Ortmann-Ajkai A, Petrík P, Pielech R, Reczynska K, Schmidt W, Standovár 895 T, Swierkosz K, Teleki B, Vild O, Wulf M, Coomes D. 2020. Forest microclimate 896 dynamics drive plant responses to warming. Science 368:772-775 DOI $897 \quad 10.1126 /$ science.aba6880. 
Figure 1

Location of the study area showing the spatial arrangement of sampling sites within and near Kaxil Kiuic Biocultural Reserve in the Yucatan Peninsula, Mexico, for each successional age category. 


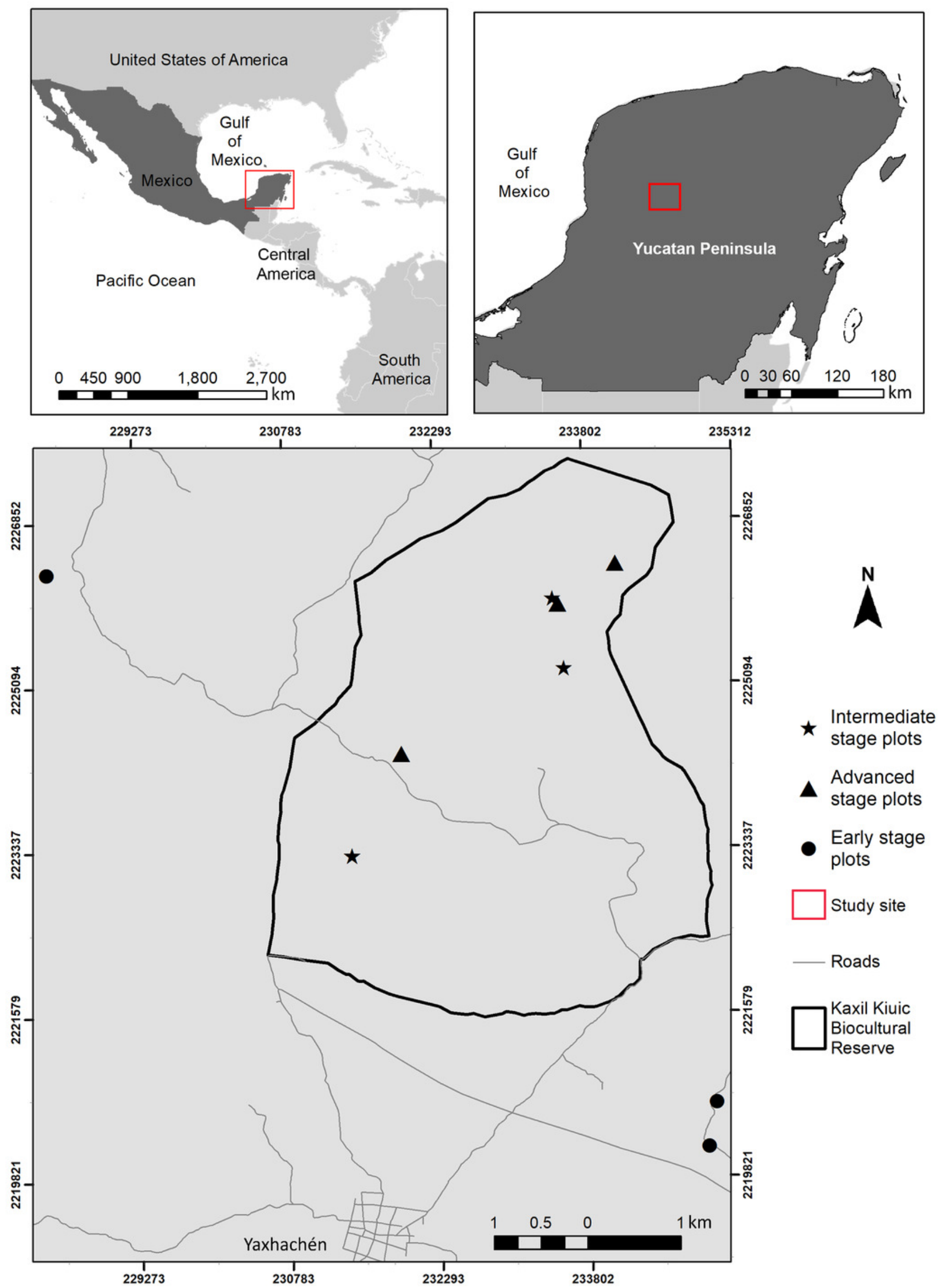

Peerj reviewing PDF | (2020:01:44799:1:2:NEW 20 Jun 2020) 


\section{Figure 2}

Predicted temporal trends for large plant density (a-c) and species density (d-f), and for small plant density $(\mathrm{g}-\mathrm{i})$ and species density $(\mathrm{j}-\mathrm{-l})$ in the dry- and rainy seasons in each successional stage.

The shaded sections correspond to $95 \%$ confidence intervals. Capital letters in each graph represent significant $(p<0.05)$ effects of predictors based on the linear mixed effects models. $D^{*}$ : dry season, $W^{*}$ : wet or rainy season, Dry $\times$ Year*: dry season $\times$ sampling year interaction. 


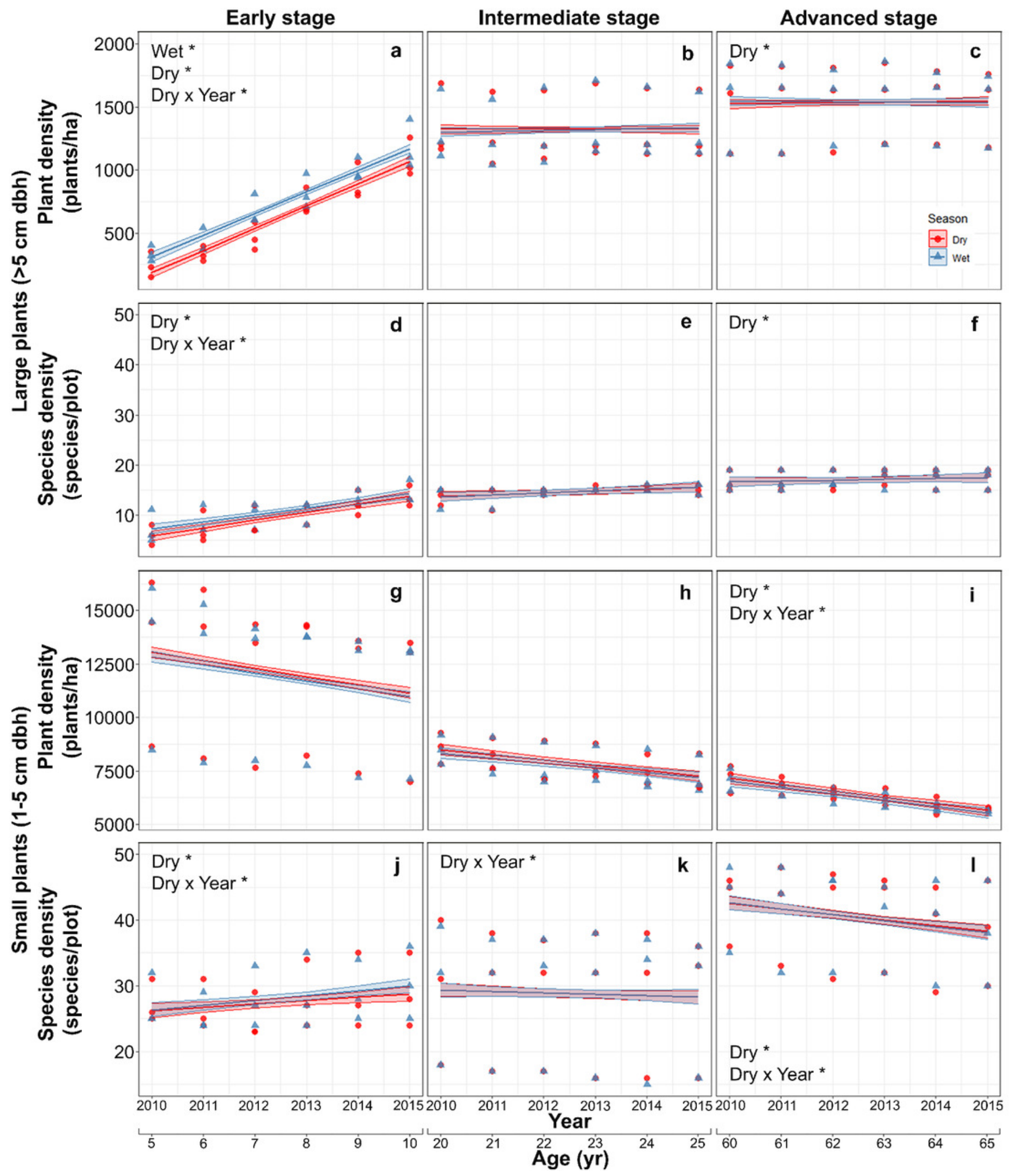




\section{Figure 3}

Predicted temporal trends for large plant recruitment $(a-c)$, species gain rate $(d-f)$, small plant recruitment $(g-i)$, species gain rate $(j-1)$ in the dry- and rainy seasons per successional stage.

The shaded sections correspond to $95 \%$ confidence intervals. Capital letters in each graph represent significant $(p<0.05)$ effects of predictors based on the linear mixed effects models. W*: wet or rainy season, Wet $\times$ Year*: wet season $\times$ sampling year interaction. 


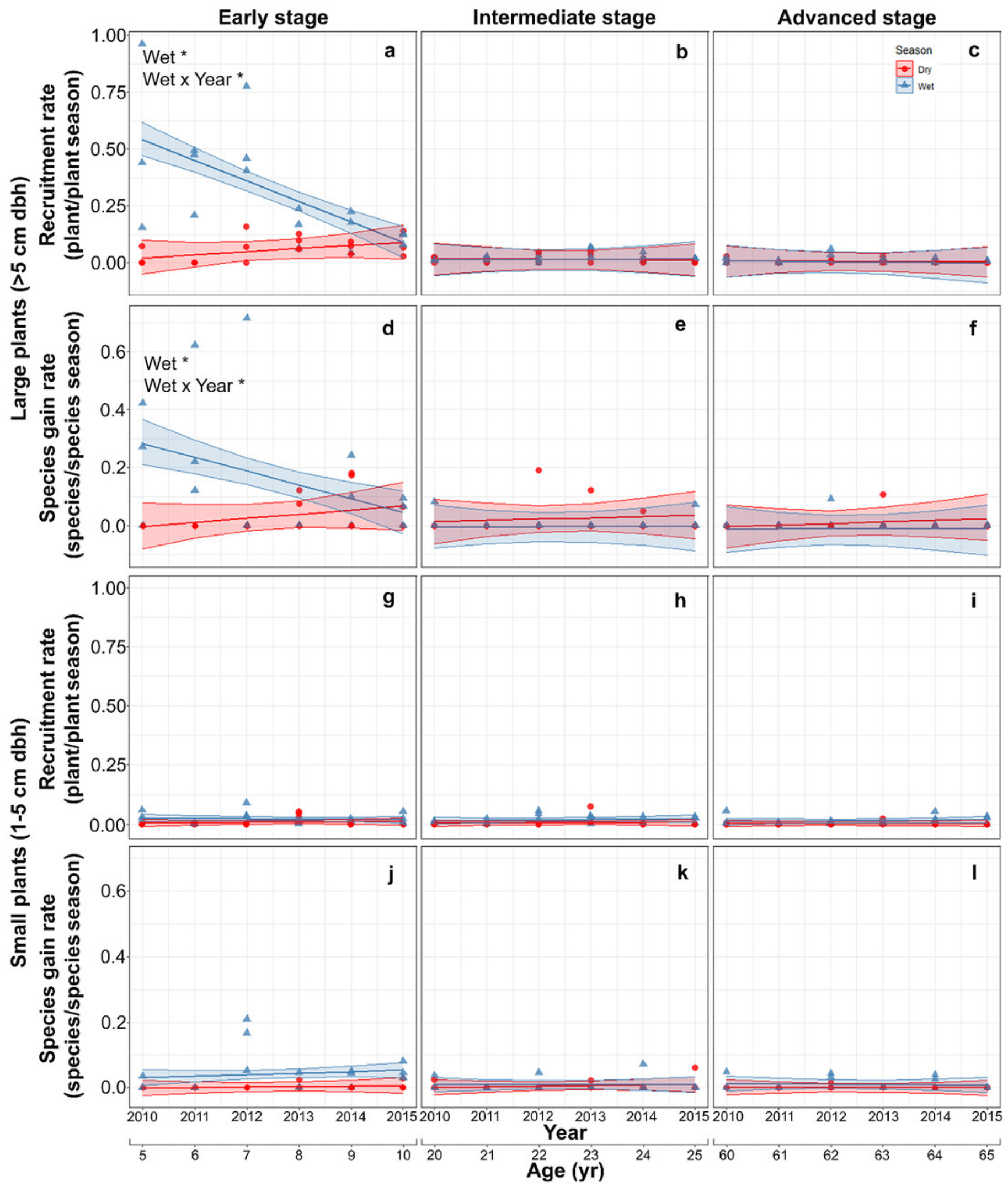




\section{Figure 4}

Predicted temporal trends for large plant mortality (a-c) and species loss rate (d-f), small plant mortality $(g-i)$ and species loss rate $(j-l)$ in the dry- and rainy seasons per successional stage.

The shaded sections correspond to $95 \%$ confidence intervals. Capital letters in each graph represent significant $(p<0.05)$ effects of predictors based on the linear mixed effects models. D*: dry season, $W^{*}$ : wet season, Wet $\times$ Year*: wet season $\times$ sampling year interaction. 


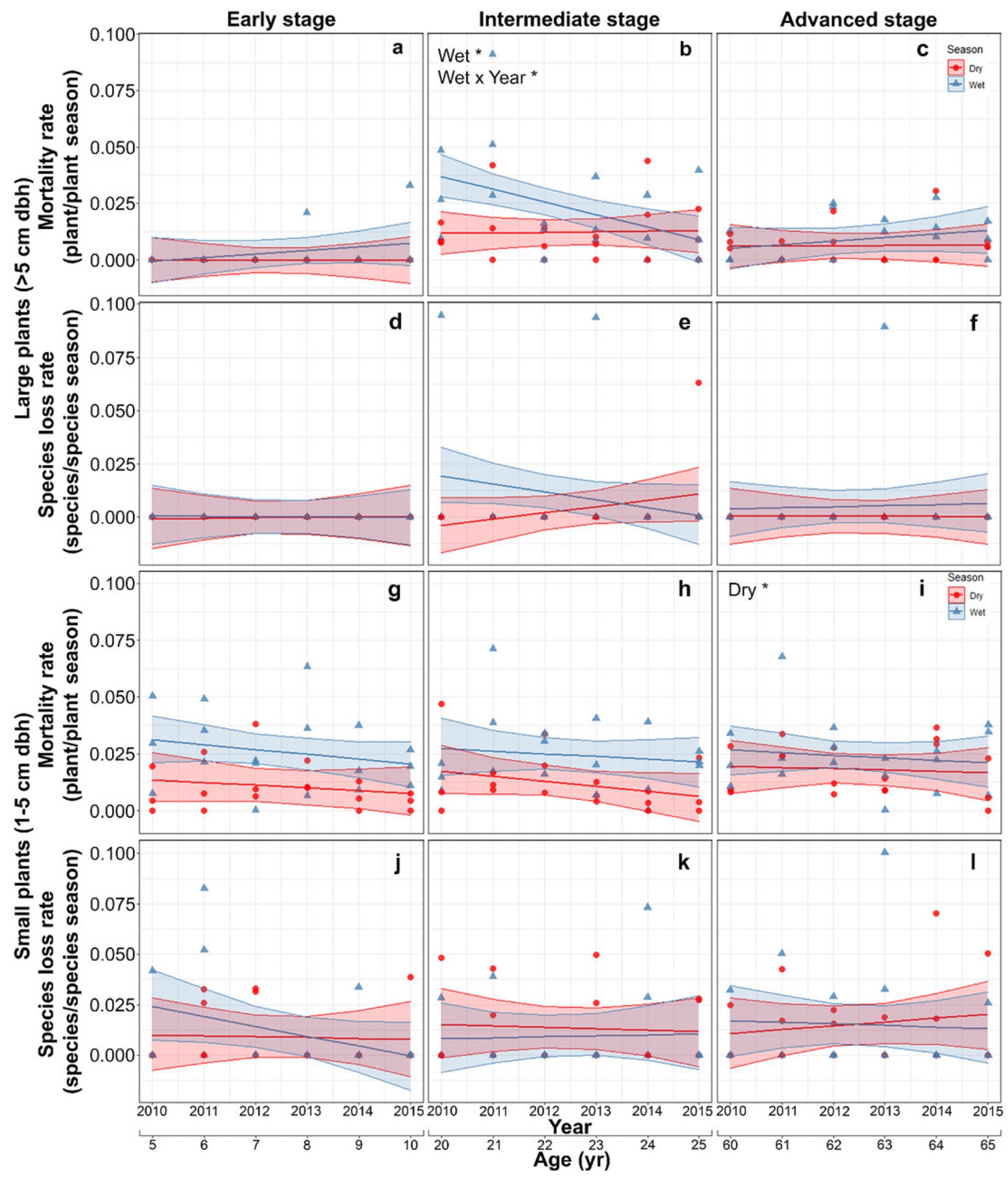

